\title{
Comparison of the perspectives of the pediatric surgeons and pediatric urologists in management of cryptorchidism in Saudi Arabia
}

Osama A. Bawazir, FRCSC, MD, Abdulrahman Maghrabi, FRCSI, MD, Omemh Abdullah Bawazeer, PhD,

Soliman Binyahib, MD, Razan Bawazir, MS, Nawaf Halabi, MS, Abdullah Bawazir, MS.

\begin{abstract}
الأهداف: تقييم التباين في وجهات النظر بين جراحي الأطفال وأطباء المسالك البولية للأطفال في علاج الخصية المعلقة.

المنهجية : أجرينا هذا الاستطلاع بين جراحي الأطفال واستشاريين المسالك البولية للأطفال

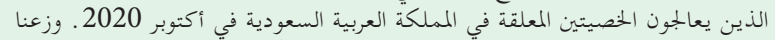

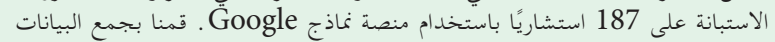

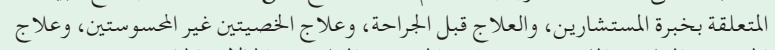

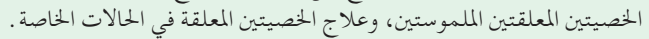

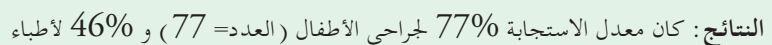

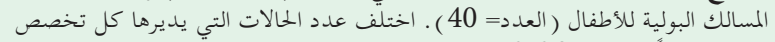

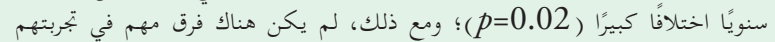

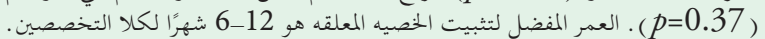

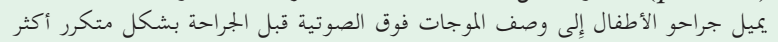

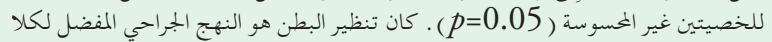

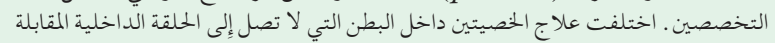

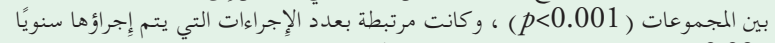

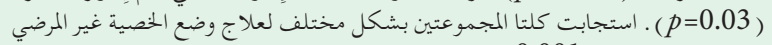

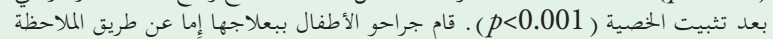

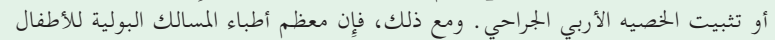

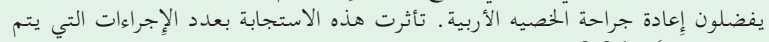
إِجراؤها سنويًا (

الحلاصة: في المملكة العربية السعودية، لدى جراحي الأطفال وأطباء المسالك البولية

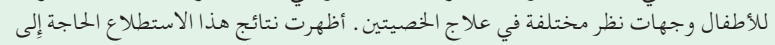

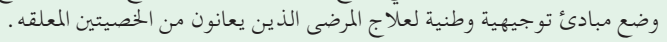

Objectives: To evaluate the variability in perspectives between pediatric surgeons and pediatric urologists in managing cryptorchidism.

Methods: We conducted this survey among pediatric surgeons and pediatric urologists managing cryptorchidism in Saudi Arabia in October 2020. We distributed a questionnaire to 187 consultants using the Google forms platform. We collected data related to the consultant's experience, preoperative management, management of nonpalpable testes, management of palpable undescended testes, management of the cryptorchidism in special situations.

Results: The response rate was $77 \%$ for pediatric surgeons $(n=77)$ and $46 \%$ for pediatric urologists $(n=40)$. The number of cases managed by each specialty per year differed significantly $(p=0.02)$; however, there was no significant difference in their experience $(p=0.37)$. The preferred age for orchidopexy was 6-12 months for both specialties. Pediatric surgeons tend to prescribe preoperative ultrasound more frequently for nonpalpable testes $(p=0.05)$. Laparoscopy was the preferred surgical approach by both specialties. Management of intraabdominal testes not reaching the contralateral internal ring differed between groups $(p<0.001)$, and it was related to the number of procedures performed annually $(p=0.03)$. Both groups responded differently to the management of unsatisfactory testicular position after orchidopexy $(p<0.001)$. Pediatric surgeons managed it with either observation or re-operative inguinal orchidopexy; however, most pediatric urologists preferred re-operative inguinal orchidopexy. This response was affected by the number of procedures performed annually $(p=0.04)$.

Conclusion: In Saudi Arabia, practicing pediatric surgeons and pediatric urologists have different perspectives in the management of cryptorchidism. The results of this survey demonstrated the need to establish national guidelines to manage patients with cryptorchidism.

Keywords: cryptorchidism, survey, pediatric surgeons, pediatric urologists

Saudi Med J 2021; Vol. 42 (5): 555-561

doi: 10.15537/smj.2021.42.5.20210007

From the Department of Surgery (Bawazir O), Faculty of Medicine, Umm Al-Qura University; from the Pediatric Surgery Department (Maghrabi), Maternity and Children Hospital, Makkah; and from the College of Medicine (Binyahib, Bawazir R, Halabi, Bawazir A), King Saud Bin Abdulaziz University for Health Sciences, Jeddah, Kingdom of Saudi Arabia.

Received 11th January 2021. Accepted 15th March 2021.

Address correspondence and reprint request to: Dr. Osama Bawazir, Associate Professor, Department of Surgery, Faculty of Medicine, Umm Al-Qura University, Makkah, Kingdom of Saudi Arabia. E-mail: obawazir@yahoo.com / oabawazir@uqu.edu.sa ORCID ID: http://orcid.org/0000-0002-4213-7377 
$\mathrm{C}$ ryptorchidism has a prevalence of $4.3 \%$ among newborn males. ${ }^{1,2}$ Most of the patients with cryptorchidism will have spontaneous descend of the testes during the first 3 months of their life and nearly $0.8-1.1 \%$ of male infants have persistent cryptorchidism. ${ }^{3,4}$ Early surgery is recommended to prevent infertility and malignancy in the patients with persistent cryptorchidism. ${ }^{5}$ Both pediatric surgeons and pediatric urologists could manage cryptorchidism, and the strategy used for management of the condition depends on the surgeons' experience. ${ }^{6}$ Cryptorchidism can be managed using different techniques, including inguinal or laparoscopic approaches, depending on the testis location and surgeons' preference and experience. ${ }^{7}$ The approach used for the treatment could differ between the pediatric surgeons and pediatric urologists, and both could use different treatment approaches for patients, either pre-operatively or surgically. The variability in treatment approach could be due to the lack of standard clinical practice guidelines or it can be affected by the speciality training that contributes to the experience-based medicine. ${ }^{8}$

In Saudi Arabia, patients with cryptorchidism are managed by either pediatric surgeons or urologists, and survey studies evaluating the difference in practice or treatment approach used by these practitioners with 2 different specialities are scarce. Therefore, this study was designed with an aim to evaluate the variability between the perspectives of the pediatric surgeons and pediatric urologists managing cryptorchidism in Saudi Arabia.

Methods. We conducted a cross-sectional survey study to evaluate the variability between the perspectives of the pediatric surgeons and pediatric urologists managing cryptorchidism in Saudi Arabia. We distributed a questionnaire to 187 consultants using the Google forms platform. Consultants currently practicing in Saudi Arabia were allowed to participate in this survey.

The questionnaire was validated based on the previous surveys and feedback from 3 consultants with some modifications as per objectives of our study. We distributed the questionnaire form in October 2020, and data collection was open for 6 weeks. Initially inadequate response was obtained; therefore, the questionnaire was re-distributed in November

Disclosure. Authors have no conflict of interests, and the work was not supported or funded by any drug company.
2020. We collected data related to the consultant's experience, preoperative management, management of nonpalpable testes, management of palpable undescended testes, management of the cryptorchidism in special situations. The questionnaire form can be retrieved from the following link https://docs. google.com/forms/d/e/1FAIpQLScNWBTZ-RegvA dzMW8Gw2hAwmqShM115RxaqduRrvx0e4-RKQ/ viewform? $\mathrm{vc}=0 \& \mathrm{c}=0 \& \mathrm{w}=1 \& \mathrm{flr}=0$

The local ethical committee approved the survey items, and the respondents provided written consent to participate in this study.

Statistical analysis. The response obtained was compared between the pediatric surgeons and pediatric urologists using the Chi-square or Fisher exact test which ever appropriate. Data was presented as numbers and percentages. A $p$-value $<0.05$ was considered statistically significant. Stata 16.1 (Stata Corp, College Station, Texas, USA) was used to perform the analysis.

Results. We distributed the questionnaire to 100 pediatric surgeons with a response rate of $77 \%$ and 87 pediatric urologists with a response rate of $46 \%$. The response between pediatric surgeons $(n=77 ; 65.8 \%)$ and pediatric urologists $(n=40 ; 34.2 \%)$ were compared. The experience of the participants is shown in Table 1. There was a significant difference in the number of cases performed per year between both the study groups $(p=0.02)$.

Preoperative management. Most of the pediatric surgeons preferred to perform orchidopexy in the patients who were between 6 to 12 months of age, and all the pediatric urologists performed this procedure in the above-mentioned age group. The years in practice and number of procedures performed per year did not affect

Table 1 - Participants' experience.

\begin{tabular}{lccc}
\hline Variables & $\begin{array}{c}\text { Pediatric } \\
\text { surgeons } \\
(\mathbf{n}=77)\end{array}$ & $\begin{array}{c}\text { Pediatric } \\
\text { urologists } \\
(\mathbf{n}=40)\end{array}$ & $P$-value \\
\hline How many cryptorchidisms do you manage per year? & \\
$<25$ & $18(23.4)$ & $4(10.0)$ & 0.02 \\
$25-50$ & $28(36.3)$ & $9(22.5)$ & \\
$50-100$ & $21(27.2)$ & $23(57.5)$ & \\
$>100$ & $10(13.0)$ & $4(10.0)$ & \\
How many years in practice? & & \\
$<5$ & $14(18.2)$ & $10(25.0)$ & 0.37 \\
$5-10$ & $16(20.8)$ & $11(27.5)$ & \\
$>10$ & $47(61.0)$ & $19(47.5)$ & \\
\hline
\end{tabular}


the age preference of the patient ( $p=0.57$ and $p=0.18$ ). Pediatric surgeons tend to prescribe preoperative ultrasound more frequently for non-palpable testes and they also prescribed preoperative hormonal therapy more frequently (Table 2).

Management of nonpalpable testes. We did not observe a significant difference in the initial surgical approach used for unilateral and bilateral nonpalpable testes. The management was not affected by the years for which the concerned medical practitioner was in practice ( $p=0.66$ ) or the number of procedures performed annually $(p=0.25)$. The pattern differed significantly between both the specialties in the management of intra-abdominal testes. The number of procedures performed annually affected the intra-abdominal testes' management not reaching the contralateral internal ring after mobilization $(p=0.03)$ (Table 3$)$.

Management of palpable undescended testes. There was a significant difference in the approach and timing for the management of palpable cryptorchidism in both groups. There was no relation between practice years, number of cases performed, and the choice of the approach or timing. Vicryl (polyglactin) was the most common material used to fix the testes during orchidopexy (Table 4).

Management of the cryptorchidism in special situations. Both groups responded differently regarding the management of unsatisfactory testicular position after orchidopexy. This response was not related to the years of practice $(p=0.64)$, but was associated with the number of procedures performed annually $(p=0.04)$. There was no difference in cryptorchidism management in patients with cerebral palsy and Down syndrome in both groups. Management of cryptorchidism in patients with Down syndrome was not related to the practice years $(p=0.58)$ but was related to the number of cases performed annually ( $p=0.02)$ (Table 5).

Discussion. There are no standard national guidelines for the management of cryptorchidism. Moreover, there is a possibility that the difference in the training background between medical practitioners of different specialties could affect the cryptorchidism management. Therefore, we conducted this survey to evaluate the difference in cryptorchidism management between pediatric surgeons and pediatric urologists in Saudi Arabia.

International practice guidelines were developed according to the current evidence to standardize the management of cryptorchidism. However, there are several guidelines published with reference to the management of cryptorchidism, with possible dissimilarities. ${ }^{10-13}$ A critical assessment of these guidelines suggested the similarity between them in terms of quality and overall recommendations. ${ }^{14}$ Still, the practice and approach used for the management of cryptorchidism could be affected by these multiple guidelines, especially in countries where medical practitioners of different specialties follow different guidelines.

We observed differences in the management of cryptorchidism between pediatric surgeons and urologists in Saudi Arabia. The survey included consultants of both the specialties with no significant

Table 2 - Pre-operative management.

\begin{tabular}{|c|c|c|c|}
\hline Management & $\begin{array}{c}\text { Pediatric } \\
\text { surgeons } \\
(\mathbf{n}=77)\end{array}$ & $\begin{array}{l}\text { Pediatric } \\
\text { urologists } \\
(\mathrm{n}=40)\end{array}$ & $P$-value \\
\hline \multicolumn{4}{|c|}{ What is your preferred age of orchidopexy? (months) } \\
\hline $3-6$ & $4(5.2 .0)$ & 0 & $<0.001$ \\
\hline $6-12$ & $58(75.3)$ & $40(100)$ & \\
\hline$>12$ & $15(19.5)$ & 0 & \\
\hline \multicolumn{4}{|c|}{ Do you routinely order ultrasounds for nonpalpable testes? } \\
\hline Yes & $28(36.4)$ & $7(17.5)$ & 0.05 \\
\hline \multicolumn{4}{|c|}{ Do you routinely order MRI for nonpalpable testes? } \\
\hline Yes & $3(3.9)$ & 0 & 0.55 \\
\hline \multicolumn{4}{|c|}{ Do you use hormonal therapy for cryptorchidism? } \\
\hline No & $64(83.1)$ & $37(92.5)$ & 0.01 \\
\hline If intra-abdominal testes & $2(2.6)$ & $3(7.5)$ & \\
\hline If small bilateral testes & $11(14.3)$ & 0 & \\
\hline
\end{tabular}


Table 3 - Management of nonpalpable testes.

\begin{tabular}{|c|c|c|c|}
\hline Management & $\begin{array}{c}\text { Pediatric } \\
\text { surgeons } \\
(\mathrm{n}=77)\end{array}$ & $\begin{array}{c}\text { Pediatric } \\
\text { urologists } \\
(\mathrm{n}=40)\end{array}$ & $P$-value \\
\hline \multicolumn{4}{|l|}{$\begin{array}{l}\text { What is your preferred initial surgical approach to unilateral } \\
\text { nonpalpable testes? }\end{array}$} \\
\hline Laparoscopic & $74(96.1)$ & $38(95.0)$ & 0.74 \\
\hline Inguinal & $2(2.6)$ & $2(5)$ & \\
\hline Examination under Ga if not palpable laparoscopic exploration & $1(1.3)$ & 0 & \\
\hline \multicolumn{4}{|l|}{$\begin{array}{l}\text { What is your preferred initial surgical approach for bilateral } \\
\text { nonpalpable testes? }\end{array}$} \\
\hline Laparoscopic & $77(100)$ & $40(100)$ & \\
\hline \multicolumn{4}{|l|}{$\begin{array}{l}\text { What is your preferred timing for bilateral nonpalpable undescended } \\
\text { testes? }\end{array}$} \\
\hline Synchronous & $50(64.9)$ & $32(80)$ & 0.09 \\
\hline Metachronous & $27(35.1)$ & $8(20)$ & \\
\hline \multicolumn{4}{|l|}{$\begin{array}{l}\text { What is your preferred initial approach for intra-abdominal testes } \\
\text { where the testis reaches the contralateral ring after mobilization? } \\
\text { (When the intra-abdominal testes can be mobilized to the } \\
\text { contralateral ring that means it have enough length to go down to } \\
\text { the scrotum). }\end{array}$} \\
\hline Laparoscopic 1-stage orchidopexy & $68(88.3)$ & $33(82.5)$ & 0.001 \\
\hline $\begin{array}{l}\text { Staged laparoscopic testicular vessel elongation/Traction, } \\
\text { followed by inguinal orchidopexy (Shehata Technique) }\end{array}$ & $5(6.5)$ & 0 & \\
\hline Laparoscopic 2-stage Fowler-Stephens orchidopexy & $1(1.3)$ & $7(17.5)$ & \\
\hline Inguinal 1-stage orchidopexy & $3(3.9)$ & 0 & \\
\hline \multicolumn{4}{|l|}{$\begin{array}{l}\text { What is your preferred initial approach for intra-abdominal testes } \\
\text { where the testis does not reach the contralateral internal ring after } \\
\text { mobilization? }\end{array}$} \\
\hline Laparoscopic 1 stage orchidopexy & $7(9.1)$ & $2(5)$ & $<0.001$ \\
\hline Laparoscopic 2-stage Fowler-Stephens orchidopexy & $37(48.1)$ & $38(95)$ & \\
\hline $\begin{array}{l}\text { Staged laparoscopic testicular vessel elongation/Traction, } \\
\text { followed by inguinal orchidopexy (Shehata Technique) }\end{array}$ & $33(42.9)$ & 0 & \\
\hline
\end{tabular}

Table 4 - Management of palpable undescended testes

\begin{tabular}{|c|c|c|c|}
\hline Management & $\begin{array}{c}\text { Pediatric } \\
\text { surgeons } \\
(\mathrm{n}=77)\end{array}$ & $\begin{array}{c}\text { Pediatric } \\
\text { urologists } \\
(\mathrm{n}=40)\end{array}$ & $P$-value \\
\hline \multicolumn{4}{|l|}{ What is your preferred approach for palpable undescended testes? } \\
\hline Depends on the position of the testes & $25(32.5)$ & $31(77.5)$ & $<0.001$ \\
\hline Inguinal, standard 2-incision orchidopexy & $52(67.5)$ & $7(17.5)$ & \\
\hline Scrotal, single incision orchidopexy & 0 & $2(5.0)$ & \\
\hline \multicolumn{4}{|l|}{ What is your preferred timing for bilateral palpable undescended testes? } \\
\hline Synchronous & $66(85.7)$ & $40(100)$ & 0.02 \\
\hline Metachronous & $11(14.3)$ & 0 & \\
\hline \multicolumn{4}{|l|}{ What kind of sutures do you use to fix the testes during the orchidopexy? } \\
\hline $\begin{array}{l}\text { I do not fix the testis. I pass it through a window in the scrotal } \\
\text { septum }\end{array}$ & $1(1.3)$ & 0 & 0.72 \\
\hline Vicryl & $65(84.4)$ & $36(90)$ & \\
\hline Absorbable monofilament like Maxon & $1(1.3)$ & 0 & \\
\hline Polysorb & $2(2.6)$ & 0 & \\
\hline PDS & $1(1.3)$ & 0 & \\
\hline Prolene & $2(2.6)$ & $4(10.0)$ & \\
\hline No fixation & $1(1.3)$ & 0 & \\
\hline Ethibond & $2(2.6)$ & 0 & \\
\hline No suture only good mobilization & $1(1.3)$ & 0 & \\
\hline No tension (absorbable) tension (non absorbable) & $1(1.3)$ & 0 & \\
\hline
\end{tabular}


Table 5 - Management of cryptorchidism in special situations.

\begin{tabular}{|c|c|c|c|}
\hline Management & $\begin{array}{l}\text { Pediatric surgeons } \\
\quad(\mathrm{n}=77)\end{array}$ & $\begin{array}{l}\text { Pediatric urologists } \\
\qquad(n=40)\end{array}$ & $P$-value \\
\hline \multicolumn{4}{|c|}{$\begin{array}{l}\text { What do you do for an unsatisfactory } \\
\text { testicular position after orchidopexy? }\end{array}$} \\
\hline Observe & $40(52.0)$ & $6(15.0)$ & $<0.001$ \\
\hline Redo inguinal orchidopexy & $37(48.1)$ & $34(85.0)$ & \\
\hline \multicolumn{4}{|c|}{$\begin{array}{l}\text { How you manage cryptorchidism in } \\
\text { cerebral palsy children with severe } \\
\text { disability }\end{array}$} \\
\hline Nothing & $23(29.9)$ & $6(15.0)$ & 0.11 \\
\hline Orchidopexy & $53(68.8)$ & $34(85.0)$ & \\
\hline Orchidectomy & $1(1.3)$ & 0 & \\
\hline \multicolumn{4}{|c|}{$\begin{array}{l}\text { How do you manage cryptorchidism in } \\
\text { children with down syndrome? }\end{array}$} \\
\hline Nothing & $3(3.9)$ & 0 & 0.55 \\
\hline Orchidopexy & $74(96.1)$ & $40(100)$ & \\
\hline \multicolumn{4}{|c|}{$\begin{array}{l}\text { At what age will you do orchiectomy rather } \\
\text { than orchidopexy for the undescended } \\
\text { testes? (years) }\end{array}$} \\
\hline$<10$ & $6(7.8)$ & 0 & 0.01 \\
\hline $10-15$ & $8(10.4)$ & $13(32.5)$ & \\
\hline $15-20$ & $24(31.2)$ & $11(27.5)$ & \\
\hline$>20$ & $39(50.7)$ & $16(40.0)$ & \\
\hline
\end{tabular}

difference in their practice years. However, the number of cases managed by the pediatric surgeons were significantly different, demonstrating the referral pattern of cryptorchidism.

According to the current recommendations, orchidopexy is typically performed within 6-12 months after the birth of male child. Pre-operative ultrasound is not essential for the diagnosis and open or laparoscopic approaches can be offered for the nonpalpable undescended testes. ${ }^{14}$ The participants' practice or treatment approach in this survey was consistent with the previously published recommendations, ${ }^{10-12,14,15}$ and most of them performed orchidopexy during the first year of the birth of the male child. However, we could not assess if the guidelines promoted a change in practice towards changing the age of orchidopexy to 18 months or not and whether the surgeons of both the specialties preferred the same treatment approach before the publication of the guidelines. Additionally, we observed that despite the recurrent recommendations, 30\% of the surgeons still request for preoperative ultrasound and $4 \%$ for MRI. Preoperative imaging could improve the diagnosis in obese children or could be carried out for medicolegal reasons.

The approach used for the management of palpable testes differed significantly between the medical practitioners in both specialties. Pediatric surgeons preferred the inguinal approach, while pediatric urologists had no clear preference. Management approach used by pediatric urologists 'depends on the testes' position. They used the inguinal approach if the testes was below the deep inguinal ring and the laparoscopy was preserved for intra-abdominal testes. Despite the difference in response, it was found to be consistent with the current guidelines which indicated that both approaches are adequate. Moreover, the results obtained in this study were consistent with a previous study comparing the management of testicular torsion between pediatric surgeons and urologists in Saudi Arabia. ${ }^{16}$

On the other hand, both the groups agreed on the same approach for managing nonpalpable testes, and laparoscopy was their preferred approach for both unilateral and bilateral undescended testes. This response was found to be consistent with the American Urological Association guidelines which stated that laparoscopy is the preferred method; however, both laparoscopy and open approaches are acceptable options. ${ }^{13}$ This response was also consistent with the other guidelines, such as the Canadian Urological Association and British Association of Pediatric Surgeons guidelines which stated that both approaches are acceptable. ${ }^{10,11,13}$ Unless the laparoscopist and equipment are unavailable, laparoscopy is the first choice for the nonpalpable testes and inguinal surgery is the first choice for palpable ones. 
We investigated the timing for approaching bilateral cryptorchidism, whether synchronous or metachronous. Pediatric urologists preferred to approach bilateral cryptorchidism synchronously, but this did not reach a significant level. There are no guidelines recommendations for the management of timing for bilateral cryptorchidism. Therefore, it is not known whether a synchronous or metachronous approach could have different outcomes or costs. Additionally, the family perspectives about the timing have not been explored. All these issues should be considered when developing guidelines regarding the timing for the management of bilateral cryptorchidism.

Several suturing techniques and materials are used to fix the testes. The common practice in Saudi Arabia is the use of non-absorbable sutures. However, suturing through the testicular parenchyma may be associated with long-term complications. Coughlinet $\mathrm{al}^{17}$ found that the use of sutures to fix the testes was associated with infertility. Moreover, in animal studies, the use of sutures through the testes was associated with a local inflammatory reaction, which occurred irrespective of the type of the suture material or size. ${ }^{18}$ Therefore, it is recommended to assess the testicular function postoperatively by measuring the level of inhibin $\mathrm{B} .{ }^{19} \mathrm{We}$ did not find a significant difference in the management of cryptorchidism based on years in practice. This finding was in contrast with the Society of Pediatric Urology survey, which found a difference in the surgical approach based on the years in practice. ${ }^{6}$ Our results showed a significant difference in the management of complex and unusual scenarios based on the number of procedures performed per year rather than the number of years in practice.

Generally, the difference in the treatment approach used can exist between practitioners of different specialties. This difference can be attributed to the difference in training programs, the familiarity with surgical approaches, the number of cases performed per year and the "culture" in respective specialties. This study highlighted some of the factors that may affect the surgeons' choices and practice patterns. Understanding these factors will help in development of a universal practice guide for the management of common surgical problems. This survey is not the first study to show a difference in practice patterns between pediatric surgeons and urologists in Saudi Arabia but a step towards development of a standard practice pattern. ${ }^{16}$

Study limitations. The major limitation of the study is the small number of respondents, despite our efforts to reach most consultants dealing with cryptorchidism in Saudi Arabia. Another limitation is the generalizability. We studied the response in surgeons practicing in Saudi Arabia, and the results could not be generalized globally. The survey results should be interpreted with caution because of the low response rate and the possibility of recall biases.

In conclusion, pediatric surgeons and pediatric urologists practicing in Saudi Arabia adopt different perspectives in the management of cryptorchidism. The practice could be affected by training and number of cases performed rather than the years of experience. The results of this survey demonstrated the need to establish national guidelines for the management of patients with cryptorchidism. The use of national guidelines could improve patient outcomes and can lead to coherence in treatment protocols used among surgeons of the same or different specialties.

Acknowledgment. We would like to thank Manuscript Edit (www.manuscriptedit.com) for English language editing.

\section{References}

1. Wagner-Mahler K, Kurzenne JY, Delattre I, Bérard E, Mas JC, Bornebush L, et al. Prospective study on the prevalence and associated risk factors of cryptorchidism in 6246 newborn boys from Nice area, France. Int J Androl 2011; 34 (5 Pt 2): e499-510.

2. Mouriquand PD. Undescended testes in children: the paediatric urologist's point of view. Eur J Endocrinol 2008; 159 Suppl 1: S83-S86.

3. Barthold JS, Gonzalez R. The epidemiology of congenital cryptorchidism, testicular ascent and orchiopexy. J Urol 2003; 170: 2396-2401.

4. Kim JK, Chua ME, Ming JM, Lee MJ, Kesavan A, Kahn N, et al. Variability among Canadian pediatric surgeons and pediatric urologists in the management of cryptorchidism in boys before the publication of major guidelines: a retrospective review of a single tertiary centre. Can J Surg 2019; 62: 1-6.

5. Walsh TJ, Dall'Era MA, Croughan MS, Carroll PR, Turek PJ. Prepubertal orchiopexy for cryptorchidism may be associated with lower risk of testicular cancer. J Urol 2007; 178 (4 Pt 1): 1440-1446.

6. Griffin DL, Cambareri GM, Kaplan G. Current practice for cryptorchidism: survey of pediatric urologists. Urology Practice 2017; 4: 245-250.

7. Rajimwale A, Brant WO, Koyle MA. High scrotal (Bianchi) single-incision orchidopexy: a "tailored" approach to the palpable undescended testis. Pediatr Surg Int 2004; 20: 618-622.

8. Springer A, Subramaniam R, Krall C, Fülöp G. Orchidopexy patterns in Austria from 1993 to 2009. J Pediatr Urol 2013; 9: 535-541.

9. Kim JK, Chua M, Braga L, Langer JC, Hancock BJ, Lorenzo AJ, et al. A Canadian national survey: understanding the differences in management of cryptorchidism among pediatric surgeons and pediatric urologists. J Pediatr Surg 2019; 54: 1820-1824. 
10. Tekgul S, Dogan HS, Erdem E, Hoebeke P, Kocvara R, Nijman R, et al. Guidelines on pediatric urology. Eur Soc Paediatr Urol 2015; 55: 1-110.

11. Braga LH, Lorenzo AJ, Romao RLP. Canadian Urological Association-Pediatric Urologists of Canada (CUA-PUC) guideline for the diagnosis, management, and followup of cryptorchidism. Can Urol Assoc J 2017; 11: E251-60.

12. British Association of Pediatric Surgeons. Commissioning Guide: Paediatric Orchidopexy for Undescended Testis. NICE; 2015. London (UK): British Association of Urologic Surgeons, Royal College of Surgeons; 2015.

13. Kolon TF, Herndon CD, Baker LA, Baskin LS, Baxter CG, Cheng EY, et al. Evaluation and treatment of cryptorchidism: AUA guideline. J Urol 2014; 192: 337-345.

14. Kim JK, Chua ME, Ming JM, Santos JD, Zani-Ruttenstock E, Marson A, et al. A critical review of recent clinical practice guidelines on management of cryptorchidism. J Pediatr Surg 2018; 53: 2041-2047.
15. Penson DF, Krishnaswami S, Jules A, Seroogy JC, McPheeters ML. Evaluation and Treatment of Cryptorchidism [Internet]. Rockville (MD): Agency for Healthcare Research and Quality (US); 2012 Dec. Report No.: 13-EHC001-EF.

16. Almaramhy HH. Surgical practice among pediatric surgeons and pediatric urologists in the Kingdom of Saudi Arabia for the management of suspected testicular torsion. Saudi Med J 2018; 39: 1232-1237.

17. Coughlin MT, Bellinger MF, LaPorte RE, Lee PA. Testicular suture: a significant risk factor for infertility among formerly cryptorchid men. J Pediatr Surg 1998; 33: 1790-1793.

18. Dixon TK, Ritchey ML, Boykin W, Harper B, Zeidman E, Thompson IM. Transparenchymal suture fixation and testicular histology in a prepubertal rat model. J Urol 1993; 149: 1116-118.

19. Brugo-Olmedo S, De Vincentiis S, Calamera JC, Urrutia F, Nodar F, Acosta AA. Serum inhibin B may be a reliable marker of the presence of testicular spermatozoa in patients with nonobstructive azoospermia. Fertil Steril 2001; 76: 1124-1129. 